\title{
PEMBELAJARAN AKUNTANSI PERBANKAN MENGGUNAKAN MODEL PEMBELAJARAN CIRC
}

\author{
Budi Mulyati $^{1)}$, Reni Febriani ${ }^{2)}$, Mimin Mintarsih ${ }^{3)}$ \\ Universitas Banten Jaya \\ Serang, Indonesia \\ budimulyati@unbaja.ac.id ${ }^{1)}$, renote28@gmail.com ${ }^{2}$, miminmintarsihunbaja@gmail.com ${ }^{3)}$
}

\begin{abstract}
The aim of this research was to developed the learning planning using cooperative integrated reading and composition (CIRC) for teaching basic banking subject in vocational school level. The method in this research used $R \& D$ method and using ADDIE model (Analysis, Design, Develop, Implement, Evaluate). But in this research, researcher did not use the Evaluate phase because this research did not measure the effectiveness. The study indicated that based on the results of experts assessments (teacher and lecturer) the learning planning obtain value up to 4,35 and 3,95. Meanwhile, based on the students responses obtain value up to 3,9. So it could be concluded that in general the assessment of learning planning using CIRC Model obtain the good result. Teacher or school could also use this learning planning with CIRC model to teach the students in subject of basic banking for vocational school level.
\end{abstract}

Keywords: CIRC, Learning Planning, R\&D.

\section{A. PENDAhuluan}

Dalam proses pembelajaran, terdapat beberapa cara yang bisa digunakan guru untuk menyampaikan materi pelajaran. Beberapa diantaranya yaitu dengan cara ceramah, pemberian tugas, tanya jawab diskusi, belajar kelompok, eksperimen, karyawisata dan sebagainya. Dalam menyusun rencana pembelajaran, beberapa faktor yang menjadi bahan pertimbangan guru diantaranya karakteristik siswa, tujuan belajar, kegiatan belajar mengajar dan materi pelajaran, Zendrato (2016). Dinamika kegiatan belajar mengajar dapat divariasikan dengan menggunakan model pembelajaran tertentu. Penggunaan model pembelajaran ini tentu harus pula disesuaikan dengan kondisi siswa, sifat materi, bahan ajar, fasilitas-media yang tersedia serta kondisi guru sendiri, Fathurrohman (2015). Dengan adanya pemilihan model pembelajaran yang disesuaikan dengan kebutuhan kelas diharapkan materi dapat tersampaikan dengan baik sehingga materi dapat dipahami dan diserap oleh siswa dengan baik pula.

Referensi guru terhadap berbagai model pembelajaran masih terbatas. Sehingga 
dalam proses pembelajarannya masih menggunakan cara-cara yang konvensional, (Ghufron A, 2017:309; Ana, 2018:22. Dari sekian banyak model pembelajaran yang dapat digunakan, model yang sering digunakan di kelas diantaranya model pembelajaran STAD, Jigsaw, TPS, TSTS dan Looking for Couples (Kencana, N. P., Khosmas, F. Y., \& Syahruddin, 2020:1)

Dengan banyaknya model pembelajaran yang sudah dikembangkan, selayaknya dapat lebih dioptimalkan oleh guru untuk digunakan sebagai alternatif proses pembelajaran yang dapat membuat suasana belajar menjadi lebih menyenangkan. Hal tersebut tidak hanya akan memudahkan guru dalam menyampaikan materi, peserta didik pun akan menjadi semakin terbuka untuk sesuatu yang akan diterima olehnya karena aspek "Curiosity" dalam diri peserta didik terus di stimulasi dengan penggunaan model pembelajaran yang berbeda- beda.

Materi yang terkait secara langsung dalam kehidupan sehari-hari akan menjadi lebih bermakna jika dapat disampaikan dengan cara senyata mungkin kepada peserta didik. Salah satunya tentang dunia perbankan. Peserta didik yang belajar di SMK akan diberikan materi yang berkaitan dengan dunia perbankan melalui materi perbankan dasar.

Berdasarkan beberapa pengamatan dan observasi yang sudah dilakukan, penyampaian materi tentang perbankan dasar ini belum banyak memanfaatkan cara- cara kontekstual yang dapat merelasikan antara kehidupan nyata dengan yang sedang dipelajarinya di sekolah. Sehingga yang dipahami peserta didik sebatas pengetahuan teoretis. Dengan adanya penggunaan model pembelajaran tertentu, setidaknya dapat memberikan gambaran nyata kepada peserta didik, tentang keterkaitan antara apa yang berlaku di lapangan dan apa yang sedang dipelajarinya di kelas.

Pada model pembelajaran kooperatif siswa diberikan kesempatan untuk berkomunikasi dan berinteraksi sosial dengan temannya. Ada penggalian pengetahuan secara mandiri yang dilakukan peserta didik, karena interaksi sosial tadi menuntut hal demikian. Saat proses tersebut terjadi, guru bertindak sebagai motivator dan fasilitator aktivitas di kelas. Peran guru dalam penggunaan model pembelajaran kooperatif tidak mendominasi kegiatan tapi menciptakan atmosfer belajar siswa serta memberikan motivasi dan bimbingan agar siswa mengembangkan potensi dan kratifitasnya 
masing-masing, (Fathurrohman, 2015: 2). Artinya pembelajaran ini menjadi pembelajaran aktif dengan kegiatan yang dibangun sendiri oleh siswa dan mereka bertanggung jawab atas hasil pembelajarannya. Model pembelajaran koperatif terdiri dari berbagai model yang dapat diterapkan dalam setiap proses pembelajaran. Salah satu yang dapat digunakan dalam penyampaian materi tentang perbankan dasar yaitu model pembelajaran cooperative integrated reading and composition (CIRC). Model pembelajaran CIRC merupakan sebuah model pembelajaran yang komprehensif. Menurut Slavin (2005: 16) model ini dapat digunakan untuk mengajarkan cara membaca dan menulis pada kelas sekolah dasar, pada tingkat yang lebih tinggi dan juga pada sekolah menengah. Pendekatan pembelajaran kooperatif menekankan tujuan-tujuan kelompok dan tanggung jawab individual. Hal ini dikarenakan pembelajaran kooperatif dibangun atas dua teori utama yaitu teori motivasi dan kognitif dari perspektif motivasional, struktur tujuan kooperatif menciptakan sebuah situasi dimana anggota kelompok dapat sukses apabila kelompok mereka juga sukses (Slavin,2005:16). Teori kognitif menekankan pada pengaruh dari adanya kerja sama kelompok, apakah kelompok kerja siswa mencoba meraih tujuan kelompok atau tidak (Slavin, 2005:36).

Model pembelajaran CIRC ini dapat secara efektif meningkatkan kemampuan penalaran matematis siswa (Triastuti, $\mathrm{R}$ : 2014) sekaligus kemampuan berpikir kritis. Beberapa hasil penelitian yang lain menunjukkan adanya peningkatan aktivitas belajar siswa serta adanya peningkatan hasil belajar, (Niak, 2018; Acek M.J, 2019).

Dengan karakter demikian, maka penelitian ini secara garis besar dilakukan untuk mengembangkan penggunaan perencaan pembelajaran dengan menggunakan model pembelajaran kooperatif tipe (CIRC). Perencanaan dibuat untuk pelajaran perbankan dasar di mana uji coba dan penilaiannya dilakukan di SMK Pasundan 1 Kota Serang". Model pembelajaran ini digunakan dengan maksud supaya aktivitas peserta didik tidak hanya berinteraksi sosial dengan teman satu kelompok saat diskusi melainkan juga mempunyai tanggung jawab untuk membuat tugas yang dibebankan dalam kelompok tersebut dengan membuat laporan individu. Hal ini diharapkan dapat melatih siswa dalam tanggung jawab serta dapat melatih siswa untuk dapat mengidentifikasi masalah secara mendalam. 


\section{B. METODE PENELITIAN}

Penelitian ini menggunakan metode penelitian dan pengembangan, Research and Development (R\&D). Penelitian menggunakan model penelitian yang diadaptasi dari model pengembangan ADDIE (Analysis, Design, Develop, Implement, dan Evaluate). Model ini menggunakan 5 tahap yaitu tahap Analysis, Design, Development, Implementation, and Evalution. Namun, pada penelitian pengembangan ini hanya dilakukan 4 tahap yaitu Analysis, Design, Development, dan Implementation. Dikarenakan penelitian pengembangan ini hanya menilai kelayakan produk tidak sampai menilai keefektifan dari produk.

Penelitian pengembangan ini merupakan penelitian dengan model prosedural, yang menunjukkan langkahlangkah dari proses pengembangan produk. Pengembangan produk dalam penelitian ini berbentuk perangkat pembelajaran. Perangkat yang dikembangkan akan dinilai kepada ahli materi dan siswa.

Penelitian dilaksanakan di SMK Pasundan 1 Kota Serang yang beralamat JL. Raya Jakarta, Panancangan, Cipocok jaya, Serang, Banten. Penelitian ini dilaksanakan pada bulan Februari-Juli tahun 2020 .

Dalam penelitian ini peneliti menggunakan instrument berupa angket. Angket dibuat untuk ahli materi dan angket untuk uji terbatas. Adapun cakupan penilaian dalam penilaian ini adalah sebagai berikut : (1) Aspek yang dinilai oleh ahli materi adalah aspek pembelajaran dan aspek isi, (2) Aspek yang dinilai oleh siswa adalah aspek pengajaran dan penerapan model pembelajaran CIRC.

Data yang diperoleh melalui kegiatan uji coba diklasifikasikan menjadi dua, yaitu data kualitatif dan data kuantitatif. Data kualitatif berupa kritik dan saran yang dikemukakan ahli materi dan uji terbatas dihimpun untuk memperbaiki produk. Data kuantitatif yang diperoleh dari kuisioner selanjutnya dikonversikan ke data kualitatif dengan skala 5 (skala likert).

Adapun konversi skala lima tersebut menggunakan acuan konversi pada Pendekatan Acuan Patokan (PAP) yang dikembangkan oleh Eko Putro Widoyoko (2009: 238) sebagaimana tabel berikut ini;

Tabel 1. Konversi Nilai

\begin{tabular}{lccl}
\hline \multirow{2}{*}{$\begin{array}{c}\text { Data } \\
\text { Kuan } \\
\text { titatif }\end{array}$} & Rumus & Kriteria \\
\cline { 2 - 3 } 5 & & $\begin{array}{c}\text { Rerata } \\
\text { Skor }\end{array}$ & \\
4 & $\mathrm{X}>\mathrm{Xi}+1,8 \mathrm{Sbi}$ & $>4,2$ & Sangat Baik \\
3 & $\mathrm{Xi}+0,6 \mathrm{Sbi}<\mathrm{X} \leq \mathrm{Xi}+1,8$ & $3,4 \leq 4,2$ & Baik \\
2 & $\mathrm{Xi}+0,6 \mathrm{Sbi}$ & $2,6 \leq 3,4$ & Cukup \\
1 & $\mathrm{Xi}+1,8$ Sbi & $1,8 \leq 2,6$ & Kurang \\
& $\mathrm{X} \leq \mathrm{Xi}-1,8$ Sbi & $\leq 1,8$ & Sangat \\
& & & Kurang \\
\hline
\end{tabular}

Sumber: Eko Putro Widoyoko (2009:238) 


\section{HASIL PENELITIAN DAN} PEMBAHASAN

\section{Pengembangan \\ Pembelajaran CIRC}

Prosedur penelitian pengembangan (research and development) merupakan adaptasi dari langkah-langkah penelitian dan pengembangan ADDIE yang dikembangkan oleh Dick and Carry dalam merancang sistem pembelajaran (Endang Mulyatiningsih, 2012:200) yaitu: Analysis, Design, Development, Implementation, and Evaluations. Peneliti hanya membatasi penelitian ini sampai pada tahap Implementation. Langkah penelitian tersebut digambarkan sebagai berikut:

a. Tahap Analisis

Tahap analisis dilakukan dengan melakukan observasi di SMK Pasundan I Kota Serang. Hasil analisis akan digunakan sebagai acuan pengembangan produk perangkat pembelajaran (RPP yang sudah dimodifikasi).

b. Tahap Desain

Tahap ini berupa adanya pembuatan perangkat pembelajaran (RPP) yang merupakan dokumen yang dibuat guru sebelum mengajar di dalam kelas. RPP dibuat oleh guru untuk membantu dalam mengajar agar sesuai dengan standar kompetensi dan kompetensi dasar pada hari tersebut. RPP berisi pengaturan yang berkenaan dengan perkiraan atau proyeksi tentang apa yang akan dilakukan pada saat kegiatan belajar mengajar berlangsung. Apabila perencanaan disusun secara baik maka proses dan hasil pembelajaran tidak akan jauh dari perkiraan.

c. Tahap Pengembangan

Dalam tahap ini RPP yang sudah ada yang dibuat oleh guru kemudian dikembangkan kembali dengan peneliti dengan cara memodifikasi dan mengembangkan RPP menjadi lebih lengkap dan menarik untuk dibaca. Didalam RPP yang menggunakan model CIRC terdapat kompetensi dasar dan indikator, metode dan model pembelajaran, kegiatan pembelajaran serta gambar atau alur pembelajaran kooperatif tipe CIRC.

d. Tahap Implementasi

Pada tahap ini yaitu, peneliti melakukan implementasi pembelajaran dalam proses pembelajaran melalui aplikasi google class room dan whatsapp secara daring. Uji coba dilakukan kepada peserta didik kelas X Akuntansi SMK Pasundan I Kota Serang untuk mengetahui respon peserta didik dalam pembelajaran dengan menggunakan model CIRC. 


\section{Penilaian Ahli Materi Guru dan}

\section{Dosen}

Terdapat dua aspek yang dinilai yaitu aspek tampilan RPP yang sudah dimodifikasi dan aspek isi RPP yang sudah dimodifikasi. Berikut ini adalah tabel yang berisi penilaian ahli materi guru pada aspek tampilan RPP.

Tabel 2. Hasil Validasi Ahli Materi (Guru)
\begin{tabular}{clcl} 
Pada Aspek Tampilan RPP & \\
\hline No & Aspek dinilai & Skor & Kategori \\
\hline 1 & Kejelasan Instrumen Standar & 4 & Baik \\
& Kompetensi & & \\
2 & Kesesuaian KD dengan KI & 4 & Baik \\
3 & Struktur Kalimat & 5 & Sangat Baik \\
4 & Cakupan Sistematika pada & 5 & Sangat Baik \\
& indikator & & \\
5 & Kejelasan Tujuan Belajar & 4 & Baik \\
6 & Cakupan dan kedalaman & 4 & Baik \\
& tujuan & & \\
7 & Ruang lingkup materi & 4 & Baik \\
8 & Urutan pembelajaran & 5 & Sangat baik \\
9 & Tata Bahasa & 5 & Sangat Baik \\
10 & Sifat komunikatif bahasa & 5 & Sangat Baik \\
\hline
\end{tabular}

Sumber: Data Diolah, 2020

Berdasarkan hasil tabel 2, terdapat 10 butir indikator diperoleh dari aspek pembelajaran. Jumlah skor validasi pada sapek tampilan RPP oleh ahli materi (Guru) adalah 45 dengan 10 indikator, sehingga rerata hasil penilaian dari ahli materi adalah 4,5 mengacu pada tabel konversi, maka hasil penilaian dari ahli materi dalam aspek tampilan RPP adalah Sangat Baik.

Adapun hasil penilaian ahli materi guru dalam aspek isi RPP dapat dilihat dalam table 3 berikut ini.
Tabel 3. Hasil Validasi Ahli Materi (Guru) Pada Aspek Isi RPP

\begin{tabular}{clcl}
\hline No & Aspek dinilai & Skor & Kategori \\
\hline 1 & Kejelasan penyajian materi & 4 & Baik \\
2 & Sistematika penyajian materi & 4 & Baik \\
3 & Kebenaran materi & 4 & Baik \\
4 & Kesesuaian contoh dan materi & 5 & Sangat baik \\
5 & Bahasa sesuai dengan & 4 & Baik \\
6 & $\begin{array}{l}\text { Soal baik } \\
\text { kompetensi dasar }\end{array}$ & & \\
7 & $\begin{array}{l}\text { Terdapat alur CIRC dalam } \\
\text { RPP }\end{array}$ & Baik \\
8 & $\begin{array}{l}\text { Isi Materi pembelajaran } \\
\text { menarik }\end{array}$ & 4 & Baik \\
9 & $\begin{array}{l}\text { Kesesuaian penggunaan } \\
\text { animasi }\end{array}$ & 4 & Baik \\
\hline
\end{tabular}

Sumber: Data Diolah, 2020

Berdasarkan hasil tabel diatas terdapat 9 butir indikator diperoleh dari aspek pembelajaran. Jumlah skor validasi pada aspek isi RPP oleh ahli materi (Guru) adalah 38 dengan 9 indikator, sehingga rerata hasil penilaian dari ahli materi adalah 4,2 mengacu pada tabel konversi, maka hasil penilaian dari ahli materi dalam aspek isi RPP adalah Baik.

\section{Tabel 4. Hasil Validasi Ahli Materi} (Dosen) Pada Aspek Tampilan RPP

\begin{tabular}{|c|c|c|c|}
\hline No & Aspek dinilai & Skor & Kategori \\
\hline 1 & $\begin{array}{l}\text { Kejelasan Instrumen Standar } \\
\text { Kompetensi }\end{array}$ & 5 & Sangat Baik \\
\hline 2 & Kesesuaian KD dengan KI & 5 & Sangat Baik \\
\hline 3 & Struktur Kalimat & 5 & Sangat Baik \\
\hline 4 & $\begin{array}{l}\text { Cakupan Sistematika pada } \\
\text { indikator }\end{array}$ & 5 & Sangat Baik \\
\hline 5 & Kejelasan Tujuan Belajar & 5 & Sangat Baik \\
\hline 6 & $\begin{array}{l}\text { Cakupan dan kedalaman } \\
\text { tujuan }\end{array}$ & 5 & Sangat Baik \\
\hline 7 & Ruang lingkup materi & 4 & Baik \\
\hline 8 & Urutan pembelajaran & 3 & Cukup Baik \\
\hline 9 & Tata Bahasa & 4 & Baik \\
\hline 10 & Sifat komunikatif bahasa & 3 & Cukup Baik \\
\hline
\end{tabular}
Sumber: Data Diolah, 2020

Berdasarkan hasil tabel diatas terdapat 10 butir indikator diperoleh dari aspek pembelajaran. Jumlah skor validasi pada sapek tampilan RPP oleh ahli materi 
(Dosen) adalah 44 dengan 10 indikator, sehingga rerata hasil penilaian dari ahli materi tahap 1 adalah 4,4 mengacu pada tabel konversi, maka hasil penilaian dari ahli materi dalam aspek tampilan RPP adalah Baik.

Tabel 5. Hasil Validasi Ahli Materi (Dosen) Pada Aspek Isi RPP

\begin{tabular}{clcl}
\hline No & Aspek dinilai & Skor & Kategori \\
\hline 1 & Kejelasan penyajian materi & 4 & Baik \\
2 & Sistematika penyajian materi & 4 & Baik \\
3 & Kebenaran materi & 3 & Baik \\
4 & Kesesuaian contoh dan materi & 1 & Sangat baik \\
5 & Bahasa denaa & 4 & Sangat baik \\
6 & $\begin{array}{l}\text { Soal sua dengan } \\
\text { kompetensi dasar }\end{array}$ & Baik \\
7 & $\begin{array}{l}\text { Terdapat alur CIRC dalam } \\
\text { RPP }\end{array}$ & Baik \\
8 & $\begin{array}{l}\text { Isi Materi pembelajaran } \\
\text { menarik }\end{array}$ & 3 & Baik \\
9 & $\begin{array}{l}\text { Kesesuaian penggunaan } \\
\text { animasi }\end{array}$ & 1 & Baik \\
\hline
\end{tabular}

Sumber: Data Diolah

Berdasarkan hasil tabel diatas terdapat 9 butir indikator diperoleh dari aspek pembelajaran. Jumlah skor validasi pada aspek isi RPP oleh ahli materi (Dosen) adalah 25 dengan 9 indikator, sehingga rerata hasil penilaian dari ahli materi adalah 2,7. Mengacu pada tabel konversi, maka hasil penilaian dari ahli materi dalam aspek isi RPP adalah Kurang.

\section{Rekomendasi dan Saran dari Ahli}

\section{Materi Dosen dan guru}

a. Cek kembali alokasi waktu pada langkah kegiatan pembelajaran $(2 \times 45)$.

b. Cek kembali mengenai materi lembaga keuangan bukan bank
(Jelaskan sumber).

c. Kegiatan inti mengamati. Terdapat pemberian contoh namun tidak terdapat pada materi pembelajaran.

d. Belum tampak pengaplikasian metode CIRC, baru ada pembagian kelompok, sedangkan reading and composition belum terdengar.

e. Tambahkan soal uji kognitif untuk siswa.

f. RPP disesuaikan dengan format kurikulum 2013.

Setelah melakukan perbaikan terhadap perangkat pembelajaran, ahli materi memberikan penilaian kembali terhadap RPP. Berikut adalah penilaian tahap 2 yang dilakukan ahli materi (Dosen) setelah perbaikan aspek tampilan dan isi RPP.

Tabel 6. Hasil Validasi Ahli Materi (Dosen) Pada Aspek Tampilan RPP (setelah perbaikan)

\begin{tabular}{|c|c|c|c|}
\hline No & Aspek dinilai & Skor & Kategori \\
\hline 1 & $\begin{array}{l}\text { Kejelasan instrumen standar } \\
\text { kompetensi }\end{array}$ & 5 & Sangat baik \\
\hline 2 & $\begin{array}{l}\text { Kesesuaian kompetensi dasar } \\
\text { dengan kompetensi inti }\end{array}$ & 5 & Sangat baik \\
\hline 3 & Sruktur Kalimat & 5 & Sangat baik \\
\hline 4 & $\begin{array}{l}\text { Kecakupan sistematika pada } \\
\text { indikator }\end{array}$ & 5 & Sangat baik \\
\hline 5 & $\begin{array}{l}\text { Tujuan belajar yang ingin } \\
\text { dicapai }\end{array}$ & 5 & Sangat bik \\
\hline 6 & $\begin{array}{l}\text { Cakupan dan kedalaman } \\
\text { tujuan yang ingin dicapai }\end{array}$ & 5 & Sangat baik \\
\hline 7 & $\begin{array}{l}\text { Ruang lingkup materi } \\
\text { tergambar jelas dan mudah } \\
\text { dimengerti }\end{array}$ & 5 & Sangat baik \\
\hline 8 & $\begin{array}{l}\text { Urutan pembelajaran jelas } \\
\text { dan mudah diikuti }\end{array}$ & 5 & Sangat baik \\
\hline 9 & Tata bahasa & 4 & Baik \\
\hline 10 & $\begin{array}{l}\text { Sifat komunikatif bahasa } \\
\text { yang digunakan }\end{array}$ & 4 & Baik \\
\hline
\end{tabular}

Sumber: Data Diolah, 2020 
Berdasarkan hasil tabel diatas terdapat 10 butir indikator. Jumlah skor validasi pada sapek tampilan RPP oleh ahli materi (Dosen) adalah 48 dengan 10 indikator, sehingga rerata hasil penilaian dari ahli materi tahap 2 adalah 4,8. Berdasarkan pada tabel konversi, maka hasil penilaian dari ahli materi dalam aspek tampilan RPP adalah Sangat Baik.

\begin{tabular}{clcl} 
Tabel 7. Hasil Validasi Ahli Materi (Dosen) \\
Pada Aspek Isi RPP (setelah perbaikan) \\
\hline No & Aspek dinilai & Skor & Kategori \\
\hline 1 & Kejelasan penyajian materi & 5 & Sangat baik \\
2 & $\begin{array}{l}\text { Sistematika penyajian materi } \\
\text { Kebenaran materi }\end{array}$ & 5 & $\begin{array}{l}\text { Sangat baik } \\
\text { Baik }\end{array}$ \\
4 & $\begin{array}{l}\text { Kesesuaian pemberian contoh } \\
\text { dengan materi }\end{array}$ & 4 & Baik \\
5 & $\begin{array}{l}\text { Penggunaan bahasa dalam } \\
\text { RPP mudah dipahami }\end{array}$ & 4 & Baik \\
6 & $\begin{array}{l}\text { Rumusan soal sesuai dengan } \\
\text { kompetensi dasar }\end{array}$ & Cukup baik \\
7 & $\begin{array}{l}\text { Terdapat alur model CIRC di } \\
\text { dalam RPP }\end{array}$ & 4 & Baik \\
8 & $\begin{array}{l}\text { Kemenarikan isi materi } \\
\text { pembelajaran }\end{array}$ & Sangat baik \\
9 & $\begin{array}{l}\text { Penggunaan gambar untuk } \\
\text { memperjelas isi RPP dan } \\
\text { materi }\end{array}$ & Sangat kurang \\
\hline
\end{tabular}

Sumber: Data Diolah, 2020

Berdasarkan hasil tabel diatas terdapat 9 butir indikator. Jumlah skor validasi pada sapek tampilan RPP oleh ahli materi (Dosen) adalah 35 dengan 9 indikator, sehingga rerata hasil penilaian dari ahli materi adalah 3,9 mengacu pada tabel konversi, maka hasil penilaian dari ahli materi dalam aspek isi RPP adalah Baik dan layak untuk di implementasikan.

\section{Respon Peserta Didik}

Tahap uji coba produk ini dilakukan pada tanggal 6 Agustus 2020 secara Daring melalui aplikasi Whatsapp dan Zoom. Uji coba produk ini di khususkan pada peserta didik kelas X AKuntansi di SMK Pasundan I Kota Serang. Sebelum melakukan pembelajaran secara daring melalui aplikasi Whatsapp dan Zoom, terlebih dahulu peneliti memberikan penjelasan kepada peserta didik tentang bagaimana cara mengisi angket yang sudah diberikan melalui google form. Uji coba produk melibatkan 13 siswa yang ada dikelas X Akuntansi. Adapun hasil uji coba produk sebagai berikut:

Tabel 8. Respon Peserta Didik (Uji Coba di Kelas)

\begin{tabular}{|c|c|c|c|c|}
\hline No & Aspek dinilai & Skor & Rerata & Kategori \\
\hline 1 & $\begin{array}{l}\text { Petunjuk belajar sesuai } \\
\text { dengan kompetensi inti }\end{array}$ & 48 & 3,7 & Baik \\
\hline 2 & $\begin{array}{l}\text { Petunjuk belajar sesuai } \\
\text { dengan kompetensi inti dan } \\
\text { indikator pencapaian }\end{array}$ & 48 & 3,7 & Baik \\
\hline 3 & $\begin{array}{l}\text { Tujuan pembelajaran } \\
\text { dibacakan kepada siswa }\end{array}$ & 49 & 3,8 & Baik \\
\hline 4 & Kejelasan suara & 48 & 3,7 & Baik \\
\hline 5 & $\begin{array}{l}\text { Kejelasan bahasa yang } \\
\text { digunakan }\end{array}$ & 56 & 4,3 & Baik \\
\hline 6 & $\begin{array}{l}\text { Siswa diberi kesempatan } \\
\text { untuk memberikan contoh }\end{array}$ & 47 & 3,6 & Baik \\
\hline 7 & $\begin{array}{l}\text { Contoh materi dikaitkan } \\
\text { dengan kehidupan sehari-hari }\end{array}$ & 50 & 3,8 & Baik \\
\hline 8 & $\begin{array}{l}\text { Mengarahkan siswa supaya } \\
\text { ada kegiatan tanya jawab }\end{array}$ & 54 & 4,2 & Baik \\
\hline 9 & $\begin{array}{l}\text { Terjadi insteraksi pada saat } \\
\text { pembelajaran }\end{array}$ & 54 & 4 & Baik \\
\hline 10 & Pemberian penghargaan & 48 & 3,7 & Baik \\
\hline & $\begin{array}{l}\text { kepada siswa } \quad \text { yang } \\
\text { berpendapat }\end{array}$ & & & \\
\hline 11 & $\begin{array}{l}\text { Pemberian reward kepada } \\
\text { siswa yang bertanya }\end{array}$ & 51 & 3,9 & Baik \\
\hline 12 & $\begin{array}{l}\text { Siswa diberi kesempatan } \\
\text { untuk menjawab pertanyaan } \\
\text { temannya }\end{array}$ & 47 & 3,6 & Baik \\
\hline 13 & $\begin{array}{lrr}\text { Siswa ditunjuk } & \text { untuk } \\
\text { menjawab pertanyaan dari } \\
\text { temannya jika } & \text { tidak } \\
\text { memperhatikan } & \end{array}$ & 43 & 3,3 & Cukup baik \\
\hline 14 & $\begin{array}{ll}\text { Sebelum ditutup, siswa diberi } \\
\text { kesempatan } & \text { untuk } \\
\text { menyimpulkan materi } & \end{array}$ & 50 & 3,8 & Baik \\
\hline 15 & Menyimpulkan hasil diskusi & 49 & 3,8 & Baik \\
\hline
\end{tabular}


dan membahas masalah yang

telah didiskusikan

16 Sebelum pembelajaran selesai, guru menyampaikan materi selanjutnya

Sumber: Data Diolah, 2020

Berdasarkan data uji coba lapangan di kelompok kecil, diperoleh nilai rata-rata hasil penilain siswa sebesar 3,9 dari 16 indikator yang melibatkan 13 orang siswa. Sehingga penilaian siswa tersebut termasuk dalam katagori baik.

Secara umum, perbandingan ratarata hasil penilaian dari ahli materi baik guru dan dosen serta respon uji coba kepada peserta didik dapat dilihat dalam tabel berikut ini;

Tabel 9. Hasil Validasi Ahli Materi dan Uji Coba

\begin{tabular}{llll}
\hline No & Penilaian & Rerata & Kategori \\
\hline 1 & Ahli Materi Dosen & 3,95 & Baik \\
2 & Ahli Materi Guru & 4,35 & Baik \\
3 & Uji Coba Kelompok & 3,9 & Baik \\
& Kecil & & \\
\end{tabular}

Sumber: Data Diolah (2020)

Berdasarkan penilaian ahli materi (Dosen dan Guru) dan penilaian siswa pada Pengembangan pembelajaran kooperatif tipe CIRC untuk mata pelajaran perbankan dasar di SMK Pasundan I Kota Serang memiliki kelebihan sebagai berikut:

1. Perangkat pembelajaran (RPP) perbankan dasar dapat memudahkan guru untuk mengajar.

2. Perangkat pembelajarn (RPP) perbankan dasar dapat membantu siswa dalam memahami materi.

Hasil penelitian ini sejalan dengan hasil penelitian lain yang dipublikasikan oleh Mulyadin, E (2020) dimana hasil penelitiannya menunjukkan hasil yang relevan dengan penelitian ini yakni pengembangan perangkat pembelajaran CIRC yang berupa RPP, LKS dan Modul dapat dipalikasikan di sekolah. Adapun hasil penelitian Irma, N.A., \& Silalahi, L

$$
\text { menunjukkan }
$$

bahwa pengembangan model pembelajaran CIRC dapat mendukung kemampuan pemecahan masalah matematika pada siswa, hal tersebut ditandai dengan terpenuhinya kriteria valid, praktis dan efektif.

Namun demikian, beberapa keterbatasan dalam pengembangan ini yaitu:

1. Perangkat pembelajaran dikembangkan hanya mencangkup Kompetensi Dasar berupa Menganalisis Berbagai Jenis Lembaga Keungan Bank dan Bukan Bank.

2. Uji coba hanya dilakukan pada kelompok kecil, yaitu 13 siswa $\mathrm{X}$ akuntansi SMK Pasundan I Kota Serang.

3. Peneliti hanya mengetahui kelayakan Perangkat Pembelajaran (RPP), tanpa mengetahui keefektifan pengguna perangkat pembelajaran (RPP) dalam kegiatan pembelajaran. 


\section{KESIMPULAN DAN SARAN}

\section{Kesimpulan}

Berdasarkan analisis pada hasil penelitian dan pembahasan, maka dapat ditarik kesimpulan sebagai berikut:

1. Pengembangan pembelajaran kooperatif tipe CIRC untuk mata pelajaran perbankan dasar di SMK Pasundan I Kota Serang memperoleh output berupa perangkat pembelajaran (RPP).

2. Validasi lembar Perangkat Pembelajaran (RPP) dilakukan dengan dua ahli materi yaitu dosen dan guru. Berikut adalah penilaian yang dilakukan oleh kedua ahli materi.

a. Penilaian RPP berdasarkan penilaian ahli materi (Guru) memperoleh skor rata-rata 4,35 dengan kategori baik terhadap aspek materi dan kebenaran isi.

b. Penilaian RPP berdasarkan penilaian ahli materi (Dosen) pada tahap 1 memperoleh skor rata-rata sebesar 3,55 dengan kategori cukup baik terhadap aspek materi dan kebenaran isi. Selanjutnya, pada penilaian tahap 2 pada aspek materi dan kebenaran isi memperoleh skor ratarata 3,95 dengan kategori Baik.

3. Penilaian RPP berdasarkan siswa memeroleh skor rata-rata 3,9 dengan kategori baik.

\section{Saran}

Berdasarkan kesimpulan yang sudah disampaikan maka beberapa saran dalam penelitia ini sebagai berikut,

1. Hendaknya pengembangan perangkat pembelajaran ini terus dilaksanakan pada kompetensi dasar yang lain, guna menambah bahan ajar.

2. Implementasi hendaknya dilakukan kepada banyak siswa, agar dapat melihat kebermanfaatan RPP bagi siswa.

3. Pada pengembangan selanjutnya dharapkan tidak hanya sampai pada tahap impelementasi tetapi bisa sampai pada tahap revisi roduk dan pada tahap produksi massa.

\section{REFERENSI}

Acek, M. J. (2019). Penerapan Model Pembelajaran Cooperatif Integrated Reading And Composition (CIRC) Dalam Meningkatkan Hasil Belajar Dan Aktivitas Belajar Siswa Kelas Xi-Bs 5 Pada Materi Pesan Dari Dua Buku Fiksi (Novel Dan Buku Kumpulan Puisi) Yang Dibaca Di Smk Negeri 3 Banda Aceh Pada Semester Genap Tahun Ajaran 2017/2018. Jurnal Bahasa Dan Sastra, 13(1), 22-36.

Ana, N. Y. (2018). Penggunaan Model Pembelajaran Discovery Learning dalam Peningkatan Hasil Belajar Siswa di Sekolah Dasar. Jurnal Imiah Pendidikan dan Pembelajaran, 2(1).

Ekawati, R., Susetyarini, E., Pantiwati, Y., \& Husamah, H. (2016). Peningkatan Hasil Belajar Dan Kemampuan 
Berpikir Kritis Dengan Model Pembelajaran Cooperative Integrated Reading And Composition (CIRC).JPBI (Jurnal Pendidikan Biologi Indonesia), 1(3). https://ejournal.umm.ac.id/index.php /jpbi/article/view/2662.

Eko Putro Widoyoko. (2009). Evaluasi Program Pembelajaran (Panduan Praktis Bagi Pendidik dan Calon Pendidik). Yogyakarta: Pustaka Pelajar.

Fathurrohman, M. (2015). Model-Model Pembelajaran. Jogjakarta: Ar-Ruzz. Media. Tersedia online http://staffnew.uny.ac.id/upload/132 313272/pengabdian/model-modelpembelajaran.pdf.

Ghufron, A. (2017). Pengembangan Pembelajaran Berbasis Nilai-Nilai Budaya Yogyakarta Di Sekolah Dasar. Cakrawala Pendidikan, (2), 81677.

Irma, N. A., \& Silalahi, L. (2019, December). Pengembangan Model Pembelajaran CIRC (Cooperative Integrated Reading And Composite) Untuk Mendukung Kemampuan Pemecahan Masalah Matematika Siswa Di SMA Harapan Mekar TP 2017/2018. In Prosiding SiManTap: Seminar Nasional Matematika dan Terapan (Vol. 1, pp. 58-61).

Mulyadin, E., Sowanto, S., \& Dusalan, D. (2020). Pengembangan Perangkat Pembelajaran CIRC (Cooperative Integrated Reading And Composition) dalam Meningkatkan Pemahaman Matematis Pada Materi Perbandingan Siswa SMP. Supermat (Jurnal Pendidikan Matematika), 4(1), 40-51.
Niak, Y., Mataheru, W., \& Ngilawayan, D. A. (2018). Perbedaan Hasil Belajar Siswa Pada Model Pembelajaran Kooperatif Tipe CIRC Dan Model Pembelajaran Konvensional. Journal of Honai Math, 1(2), 67-80.

Slavin, Robert, E. (2005). Cooperative Learning Teori, Riset, dan Praktik. Bandung: Nusamedia.

Triastuti, R. (2014). Keefektifan Model CIRC Berbasis Joyfull Learning Terhadap Kemampuan Penalaran Matematis Siswa SMP. Unnes Journal of Mathematics Education, 3(2). https://doi.org/10.15294/ujme.v3i2.4 476

Zendrato, J. (2016). Tingkat Penerapan Rencana Pelaksanaan Pembelajaran dalam Pelaksanaan Pembelajaran di Kelas Suatu Studi Kasus di SMA Dian Harapan Jakarta. Scholaria: Jurnal Pendidikan Dan Kebudayaan, 6(2), 58-73. https://doi.org/https://doi.org/10.242 46/j.scholaria.2016.v6.i2.p58-73

Kencana, N. P., Khosmas, F. Y., \& Syahruddin, H. 2020. Persepsi Guru Dalam Penggunaan Model Pembelajaran Kooperatif Di Sekolah Menengah Kejuruan (Smk) Mandiri Pontianak. Jurnal Pendidikan dan Pembelajaran Khatulistiwa, 9(6) 
